\title{
中性子核反応による軽元素の深さ方向分析
}

\author{
米沢仲四郎 \\ 公益財団法人 日本国際問題研究所 軍縮・不拡散促進センター \\ 恶 100-0013 東京都千代田区霞が関 3 丁目 8-1 虎の門三井ビル三階 \\ （2012 年 1 月 17 日受付；2012 年 3 月 22 日掲載決定）
}

\section{Depth Profiling of Light Elements using Neutron Induced Reactions}

Chushiro YoneZawa

Center for the Promotion of Disarmament and Non-Proliferation, Japan Institute of International Affairs

3rd Floor Toranomon Mitsui Bldg., 3-8-1 Kasumigaseki, Chiyoda-ku, Tokyo 100-0013

(Received January 17, 2012 ; Accepted March 22, 2012)

\begin{abstract}
Neutron depth profiling (NDP) is a non-destructive analytical technique used for the analysis of elemental depth distributions at the near surface of materials. Profiles are determined by measuring the energy loss of charged particles produced by $(\mathrm{n}, \alpha)$ or $(\mathrm{n}, \mathrm{p})$ reactions. Technologically important light elements like B and Li are easily analyzed which are not often possible to accurately analyze by other methods. Since the use of cold neutron beams for NDP guided from nuclear reactors, the applications have expanded substantially including microelectronics. This paper reviews the fundamental principle and characteristics, analysis systems and method, as well as uses of NDP. As for applications of NDP, the paper focuses on modern applications reported since 1990s ; such as diamond, diamond like carbon (DLC) and cubic-boron nitride (c-BN), electrochromic devices, lithium ion batteries, nuclear fusion reactor materials, and high level radioactive-waste processing related materials. Finally, the author suggests starting an NDP research program using low energy guided neutrons at JRR-3M in Japan.
\end{abstract}

KEYWORDS : neutron depth profiling, light elements, boron, lithium, (n, $\alpha$ ) or (n, p) reactions

\section{1.は じめ に}

(n, $\alpha)$ あるいは（n,p）反応断面積が大きな, ホウ素 （B）およびリチウム（ $\mathrm{Li}$ ) 等の軽元素の中性子照射に よって発生する荷電粒子のエネルギー損失から,これら の元素の深さ方向の濃度分布を求めることができる。こ の分析法は, 中性子樑さ方向分析（NDP, Neutron Depth Profiling）と呼ばれ，1972 年 Ziegler らによって最初に 報告された ${ }^{1)}$ 。NDP はその後ハンガリー ${ }^{2)}$, ドイッ ${ }^{3)}$,

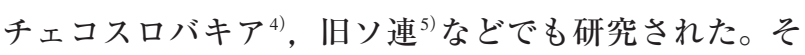
の後, 1984 年米国 NBS (NIST, National Institute Standards and Technology の前身）の研究炉 NBSR にNDP 専 用の装置が設置され ${ }^{6)}$, 研究が本格的に行われるように

E-mail : chushiro.yonezawa@cpdnp.jp
なった。NBSR には, その後冷中性子ガイドビーム施設 が設置され, NDP はさらに高感度になり, 多方面の分 野に応用されてきた ${ }^{7,8)}$ 。NBS での研究開始と同時期, 我が国でも武蔵工業大学（現在の東京都市大学）の研究 炉を使用し, NDP によるシリコン中の B の拡散係数の 測定が行われ, 太陽電池の寿命に影響する基礎データが 報告された Ziegler らの研究とほぼ同じ時期から, NDP と同様の手 法による粒子のチャネリングおよびブロッキング効果の 研究を行い ${ }^{10)}, 100$ 編以上の論文を発表している。しか し, これらの研究はNDP と目的が異なるので, 本稿で は取り上げない。

NDP は, 同種のほかの方法では分析が困難な B, Li, $\mathrm{N}$ 等の軽元素の試料表面から数 $\mu \mathrm{m}$ までの非破壊媣さ方 向分析法として, 各種半導体材料およびその素子, 薄 
Table 1. List of NDP applicable elements (Ref. 14)

\begin{tabular}{cccrrrr}
\hline Elem. & Reaction & $\begin{array}{c}\text { Abund. } \\
(\%)\end{array}$ & \multicolumn{2}{c}{$\begin{array}{c}\text { Particle energy } \\
(\mathrm{keV})\end{array}$} & $\begin{array}{c}\text { Cross-section } \\
\text { (barn) }\end{array}$ & $\begin{array}{c}\mathrm{DL}^{* *} \\
\left(\text { atoms } / \mathrm{cm}^{2}\right)\end{array}$ \\
\hline $\mathrm{He}$ & ${ }^{3} \mathrm{He}(\mathrm{n}, \mathrm{p}){ }^{3} \mathrm{H}$ & 0.00014 & 572 & 191 & 5333 & $1.5 \times 10^{12}$ \\
$\mathrm{Li}$ & ${ }^{6} \mathrm{Li}(\mathrm{n}, \alpha){ }^{3} \mathrm{H}$ & 7.5 & 2055 & 2727 & 940 & $9.0 \times 10^{12}$ \\
$\mathrm{~B}$ & ${ }^{10} \mathrm{~B}(\mathrm{n}, \alpha){ }^{7} \mathrm{Li}$ & 19.9 & 1472 & 840 & 3837 & $2.1 \times 10^{12}$ \\
$\mathrm{~N}$ & ${ }^{14} \mathrm{~N}(\mathrm{n}, \mathrm{p}){ }^{14} \mathrm{C}$ & 99.6 & 584 & 42 & 1.83 & $4.5 \times 10^{15}$ \\
$\mathrm{O}$ & ${ }^{17} \mathrm{O}(\mathrm{n}, \alpha){ }^{14} \mathrm{C}$ & 0.038 & 1413 & 404 & 0.24 & $3.5 \times 10^{16}$ \\
$\mathrm{~S}$ & ${ }^{33} \mathrm{~S}(\mathrm{n}, \alpha)^{30} \mathrm{Si}$ & 0.75 & 3081 & 411 & 0.19 & $6.0 \times 10^{16}$ \\
$\mathrm{Cl}$ & ${ }^{35} \mathrm{Cl}(\mathrm{n}, \mathrm{p})^{35} \mathrm{~S}$ & 75.8 & 598 & 17 & 0.49 & $1.7 \times 10^{16}$ \\
$\mathrm{~K}^{*}$ & ${ }^{40} \mathrm{~K}(\mathrm{n}, \mathrm{p})^{40} \mathrm{Ar}$ & 0.012 & 2231 & 56 & 4.4 & $1.9 \times 10^{15}$ \\
$\mathrm{Be}^{*}$ & ${ }^{7} \mathrm{Be}(\mathrm{n}, \mathrm{p})^{7} \mathrm{Li}$ & & 1438 & 207 & 48000 & $1.7 \times 10^{11}$ \\
$\mathrm{Na}^{*}$ & ${ }^{22} \mathrm{Na}(\mathrm{n}, \mathrm{p})^{22} \mathrm{Ne}$ & & 2247 & 103 & 31000 & $2.3 \times 10^{11}$ \\
$\mathrm{Ni}^{*}$ & ${ }^{59} \mathrm{Ni}(\mathrm{n}, \alpha)^{56} \mathrm{Fe}$ & & 4757 & 340 & 12.3 & $7.0 \times 10^{14}$ \\
\hline
\end{tabular}

* Radioactive nuclide ; ${ }^{* *}$ Detection limit based on 0.1 counts per second, $0.1 \%$ detector solid angle and a neutron intensity of $6 \times 10^{9} \mathrm{~s}^{-1}$.

膜, 多層膜, Li イオン電池, 核融合炉材料, 高レベル 放射性廃裹物等幅広い分野に応用され，これまで 100 編 を超える論文が発表されている。NDP の解説も数多く あるが, 中でも NIST の Downing らによる解説 ${ }^{11 \sim 14}$ は最 も参考になる。我が国における NDP の研究例が少ない ため, 日本語の解説はほとんど見当たらないが，文献 15）には一部取り上げられている。また, Downing が作 成した NDPのホームページ ${ }^{16} に$ に, NDP の原理や応用 等とともに，2006 年までの論文リストも掲載されてい る。本稿では, NDP の原理抒よび特徽, 装置および分 析法，そして 1990 年代以降の応用例を解説する。

\section{2. 原理および特徵}

\subsection{NDP の原理}

$(\mathrm{n}, \alpha)$ および（n,p）反応断面積が大きく，NDP が適 用可能な元素の同位体とその核デー夕を Table 1 に示 す。この中で最も適用例が多い ${ }^{10} \mathrm{~B}$ を例に, NDPの原 理を紹介する。天然に $19.9 \%$ 含まれる ${ }^{10} \mathrm{~B} に$ に低エネルギ 一中性子を照射すると，次のように反応する。

$$
\begin{aligned}
{ }^{10} \mathrm{~B}+\mathrm{n} \rightarrow{ }^{4} \mathrm{He}(1472 \mathrm{keV}) & +{ }^{7} \mathrm{Li}(840 \mathrm{keV}) \\
& +\gamma(478 \mathrm{keV}) \\
{ }^{10} \mathrm{~B}+\mathrm{n} \rightarrow{ }^{4} \mathrm{He}(1776 \mathrm{keV}) & +{ }^{7} \mathrm{Li}(1013 \mathrm{keV})
\end{aligned}
$$

${ }^{10} \mathrm{~B}$ の場合, $94 \%$ が $\gamma$ 線放出を伴った $(1)$ 式の反応が, そして残り $6 \%$ は $\gamma$ 線放出を伴わない $(2)$ 式の反応が起 こる。( 1 )と ( 2 ) 式の合計反応断面積は, 3837 barn と 非常に大きい。反応で生成する 4 種類の粒子は, Q 值か ら決まる固有のエネルギーを持ち，等方的に放出され る。しかし，個々の反応で生成する ${ }^{4} \mathrm{He}$ と ${ }^{7} \mathrm{Li}$ はそれぞ れ反対方向に放出される。 ${ }^{4} \mathrm{He}$ と ${ }^{7} \mathrm{Li}$ 粒子は, マトリッ クス原子の電子と相互作用をしてエネルギーを失ってい くが，失うエネルギー量はそれらの粒子が通過する物質

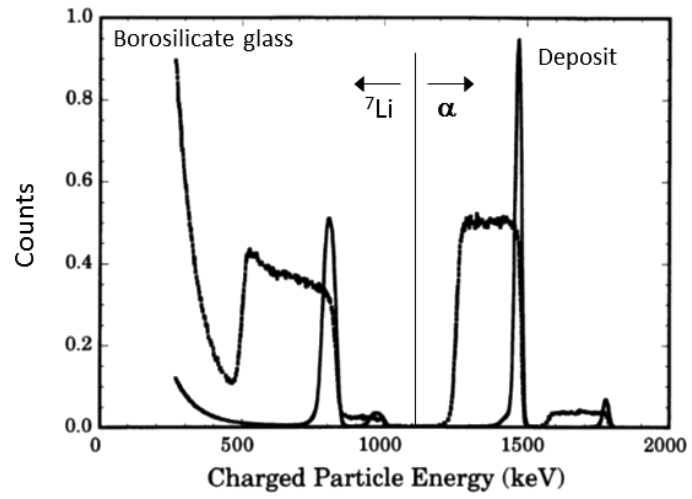

Fig. 1. Charged particle spectra obtained from a surface deposit of $B$ and from the $B$ distribution in $740 \mathrm{~nm}$ of

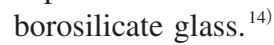

(Reprinted with permission from ref. 14. Copyright 1995, IOP Publishing Ltd.)

の種類と距離に依存する。Fig. 1 には，表面に B を薄く 蒸着した試料と, $740 \mathrm{~nm}$ 厚のホウ珪酸ガラス試料に中 性子照射し, 試料面に対して $90^{\circ}$ の角度で測定される粒 子のエネルギースペクトルを示す。ここでは, 空気によ る粒子の吸収を防ぐため, 試料の中性子照射と測定は真 空中で行われている。(1) および ( 2 )式で生成した 4 種 類の ${ }^{4} \mathrm{He}$ と ${ }^{7} \mathrm{Li}$ 粒子は, 試料厚に応じた広がりを持つピ ークとして観察される。

検出器で測定される粒子エネルギーと, その放出源の 深さ $x$ の関係は次式で表される。

$$
x=\int_{E(x)}^{E_{0}} d E / S(E)
$$

ここで， $E_{0}$ は粒子の初期エネルギー, $E(x)$ はある物質 中の深さ $x$ から放出されて検出される粒子エネルギー, そして $S(E)$ は粒子に対する物質の阻止能である。Fig. 2 
にはシリコン中における $1472 \mathrm{keV}{ }^{4} \mathrm{He}$ 粒子の透過距離 とそのエネルギーの関係を示す。図より, $1472 \mathrm{keV}{ }^{4} \mathrm{He}$ によって約 $4 \mu \mathrm{m}$ の深さまでの濃度分布を測定できるこ とが分かる。

\section{$2.2 \mathrm{NDP}$ の特徵}

$(\mathrm{n}, \alpha)$ および $(\mathrm{n}, \mathrm{p})$ 反応断面積は， $1 / \mathrm{v}$ 則によって中 性子エネルギーの平方根に反比例して大きくなる。この ため, 低エネルギーの冷中性子（約 $5 \mathrm{meV}$ )による分析 感度は, 熱中性子 $(25 \mathrm{meV})$ に比べて 2 倍以上も高い。 また，照射する中性子のエネルギーは $\mathrm{meV}$ と低く，反 応率も小さいことから, 試料の放射線損傷がなく, 生成 する放射能も無視することができる。このようなことか ら，NDP は完全な非破壊分析法で，一度測定した試料 を加熱や化学処理等をしてから再測定することも，また ほかの分析法で分析することもできる。

$(\mathrm{n}, \alpha)$ 抒よび $(\mathrm{n}, \mathrm{p})$ 反応断面積が大きな同位体は限 られ, 使用する放射線検出器は粒子以外の放射線に対し て感度が低いため, 共存元素の妨害がほとんどない。ま

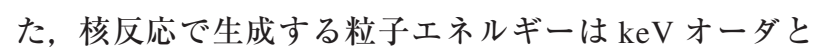
高いため, 共存元素の化学的影響もない。さらに, 標準 試料との比較によって元素を簡単に定量することができ る。このような理由により, NDP は同種の他の分析法 よりも正確さが優れている。

競合する分析法の 2 次イオン質量分析（SIMS）に比 べ，NDP は深さ分解能が劣るが，正確さが優れている。 また，原理が類似なラザフォード後方散乱（RBS）とは 良い相補関係にあり, NDP はRBS で分析が難しい軽元 素に有効である。これまで, ${ }^{3} \mathrm{He},{ }^{6} \mathrm{Li},{ }^{10} \mathrm{~B},{ }^{14} \mathrm{~N},{ }^{17} \mathrm{O}$ の NDP が報告されている。

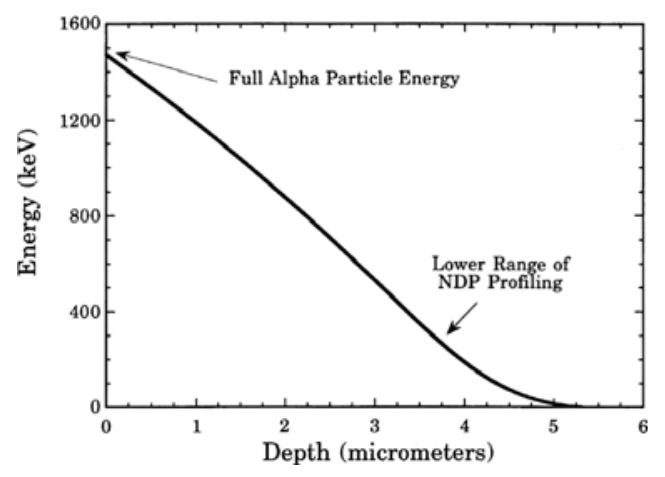

Fig. 2. The relationship between measured energy and depth for the $1472 \mathrm{keV}{ }^{4} \mathrm{He}$ particles produced by ${ }^{10} \mathrm{~B}(\mathrm{n}, \alpha){ }^{7} \mathrm{Li}$ reactions in silicon. ${ }^{14)}$

(Reprinted with permission from ref. 14. Copyright 1995, IOP Publishing Ltd.)

\section{3. 装置および分析方法}

\section{1 装置}

NDP 装置は, 中性子源, 真空チェンバー, 粒子線ス ペクトロメータ, そして中性子ビームストッパーから構 成する。1990 年代以降も NDP 研究に利用されている装 置を Table 2 に示す。この中で, NIST の装置が最も高 性能で, 研究報告数も圧倒的に多い。

中性子源: 研究炉の水平実験孔からの熱中性子ビー ム, あるいは冷中性子等のガイドビームが中性子源に用 いられる。NIST では, 初め NBSR の水平害験孔に装置 が設置されたの)。その後, NBSR には冷中性子ガイドビ 一ム施設が設置されたので，そのビームを使用する NDP 装置が設置された 初め $\mathrm{D}_{2} \mathrm{O}$ 氷の中性子源とサファイアフィルターを使用 した直線ガイド管によるものであったが, その後液体軽 水素の中性子源とスーパーミラー型曲線ガイド管に代わ った。冷中性子ガイドビームは, NDPのノイズ源とな る $\gamma$ 線と高速中性子をほとんど含まない純度の高い低工 ネルギー中性子が得られるので, NDP に最も適してい る。NIST 以外の装置は, すべて水平実験孔のビームを 使用している。放射性核種の中性子源は, 中性子束が低 いため NDP への使用例はないが, ${ }^{252} \mathrm{Cf}$ の中性子を低温 の減速材で減速し, 中性子レンズで集束したマイクロビ 一ムによる NDP が提案されている ${ }^{14)}$

真空チェンバー：(n, $\alpha)$ および $(\mathrm{n}, \mathrm{p})$ 反応で生成す る粒子を効率良く測定するため, 試料の中性子照射と粒 子線の検出は真空チェンバー内で行われる。NIST の真 空チェンバーとその中に設置される試料と検出器の配置 を Fig. 3 に示す。真空チェンバーは, 直径 $60 \mathrm{~cm}$ の円筒 形ステンレス容器で, 中性子ビームの出入り口には薄い アルミニウム板が取り付けられ, 粒子線測定におけるマ イクロフォニック雑音を避けるため, 振動の少ない夕ー ボ分子ポンプによって $10^{-2} \mathrm{~Pa}$ に減圧されている。試料 はビームに対して $45^{\circ}$ の角度で取り付けられ, 放出され

Table 2. List of NDP facilities recently utilized

\begin{tabular}{lcrc}
\hline Institution & Location & $\begin{array}{c}\text { Neutron flux } \\
\left(\mathrm{n} / \mathrm{cm}^{2} \mathrm{~s}\right)\end{array}$ & Ref. \\
\hline NIST & USA & $2.5 \times 10^{9}$ & $7), 8)$ \\
Penn State Univ. & USA & $3 \times 10^{7}$ & $17)$ \\
Univ. Texas, Austin & USA & $1.24 \times 10^{8}$ & $18)$ \\
Texas A \& M Univ. & USA & $1.4 \times 10^{7}$ & $19)$ \\
Chalk River Nucl. Lab. & Canada & $3 \times 10^{7}$ & $20)$ \\
Inst. Nucl. Phys. & Czech Rep. & $1.39 \times 10^{8}$ & $21)$ \\
Delft Univ. Technol. & Netherlands & $3 \times 10^{7}$ & $22)$ \\
Bhabha At. Res. Cent. & India & $\approx 10^{6}$ & $23)$ \\
\hline
\end{tabular}




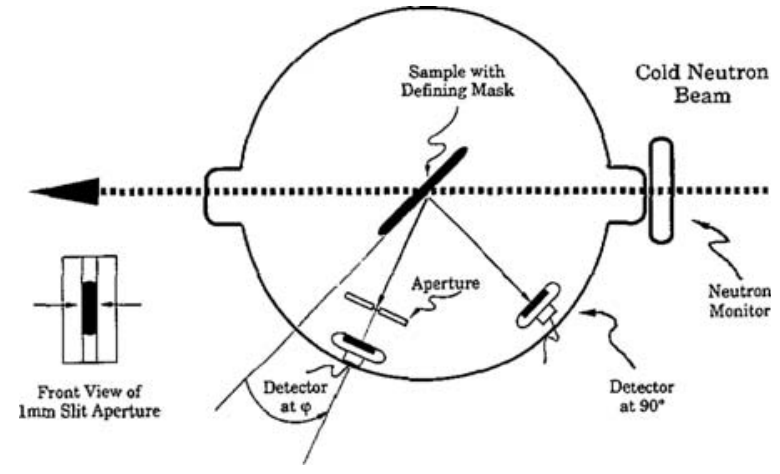

Fig. 3. A top view of the sample chamber for the NIST NDP system. ${ }^{14)}$

(Reprinted with permission from ref. 14. Copyright 1995, IOP Publishing Ltd.)

る粒子は，試料面に対して垂直 $\left(\theta=0^{\circ}\right)$ に固定した位 置と角度 $\theta=0 \sim 90^{\circ}$ に変更可能な 2 台の表面障壁型シリ コン検出器（SSD）で測定される。後者の検出器は, 深 さ分解能を高めるため, 試料の垂直面よりもさらに大き な角度での測定に使用される。検出器に異なる角度から の粒子線の入射を防ぐため, 検出器前面には幅 $1 \mathrm{~mm} の$ スリットが取りつけられている。中性子ビームの大きさ は約 $15 \mathrm{~cm}^{2}$ で, 試料位置における中性子束は $2.5 \times 10^{9}$ $\mathrm{ncm}^{-2} \mathrm{~s}^{-1}$ (熱中性子相当) ${ }^{8}$ である。ビームの大きさは 試料と分析目的によって変えられる。測定中の中性子ビ 一ム強度は，チェンバーのビーム取り入れ口に設置され たフィッションチェンバー型中性子検出器によってモニ ターされる。試料および検出器などの固定と駆動用部品 は，中性子による放射化量が少ない $\mathrm{Al}$ 製で，最大直径 $30 \mathrm{~cm}$ のシリコンウエー八を外部からの操作によって 種々の位置で測定できるようになっている。

粒子線スペクトロメータ: 粒子線の検出には, SSD が最も多く用いられる。検出器のエネルギー分解能を高 めるためには，結晶厚と電極として表面に蒸着される金 の厚さをできるだけ薄くしたものが良い。SSD 以外に は, PIN フォトダイオードやマイクロチャンネルプレー 卜（MCP）なども用いられることがある。粒子線スペ クトル測定と中性子ビームモニタリングの電子回路は, 通常の放射線計測に使用されるものと変わりがないの でこここでは紹介しない。NIST の NDP 測定システムの 電子回路構成は文献 12)を参考にされたい。

\section{2 分析方法}

粒子スペクトロメータのエネルギー校正 : ${ }^{241} \mathrm{Am}$ の $\alpha$ 線源，および ${ }^{10} \mathrm{~B}$ を薄く蒸着した試料に中性子照射して 得られる粒子線を使用して校正する。

NDP 測定：試料を真空チェンバーにセットし，減圧

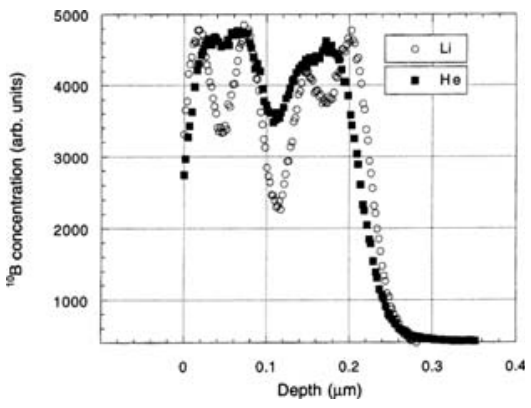

Fig. 4. Comparison of $\mathrm{B}$ depth profiles obtained from the ${ }^{4} \mathrm{He}$ and ${ }^{7} \mathrm{Li}$ charged particle spectra. ${ }^{30)}$

(Reprinted with permission from ref. 30. Copyright 1998, Elsevier Science)

下で中性子ビームを照射しながら粒子のエネルギースペ クトルを測定する。測定時間は，NIST の装置で通常 30 60 分間程度であるが，低濃度の試料や実験目的に よっては数日間の場合もある。

データ解析：得られた粒子のエネルギースペクトルの 注目する粒子ピークのエネルギー值を（３）式によって樑 さ值に変換し，元素の濃度分布曲線を作成する。測定さ れた粒子のエネルギースペクトルには，スペクトロメー 夕固有のエネルギー分解能の広がりが含まれる。このた め，予め測定されたスペクトロメー夕のエネルギー分解 能関数によってスペクトルをデコンボリューションして 分解能を補正する ${ }^{24)}$ 。マトリックスに対する測定する粒 子の阻止能は, 文献 25,26$)$ から得られる。試料が化合 物や混合物の場合, 粒子に対する各元素の阻止能を Bragg の法則に従って計算 ${ }^{27)} し て$ 求めることができる。 しかし，粒子の阻止能デー夕は限られているため，実際 は TRIM ${ }^{28)}$ と呼ばれるモンテ・カルロ計算プログラムに よって求められている。

標準物質：測定された濃度分布曲線の正確さの確認に 有用な標準物質が NIST で作製されている ${ }^{29)}$ 。この試料 （NIST SRM2137）は, SIMS の校正用としてシリコン に ${ }^{10} \mathrm{~B}$ をインプラントして調製された。試料中の ${ }^{10} \mathrm{~B}$ 濃 度分布はSIMS により， ${ }^{10} \mathrm{~B}$ 量はNDP によって正確に分 析され，認証値としてつけられている。

深さ分解能：測定する粒子と検出器の角度を変えるこ とによって, 媣さ分解能を改善することができる。通 常， ${ }^{10} \mathrm{~B}$ の分析には $1472 \mathrm{keV}$ の ${ }^{4} \mathrm{He}$ が使われるが，物質 中の阻止能がそれより大きな $840 \mathrm{keV}^{7} \mathrm{Li}$ 粒子を使用す ると深さ分解能がさらに良くなる ${ }^{30)}$ 。Fig. 4 には， ${ }^{10} \mathrm{~B}$ をドープしたダイヤモンド状非晶質炭素薄膜とドープし

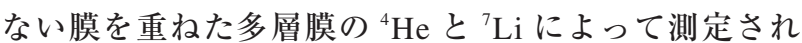
た ${ }^{10} \mathrm{~B}$ の媣さ方向分布曲線を示す ${ }^{30)}$ 。 ${ }^{4} \mathrm{He}$ では分離する 


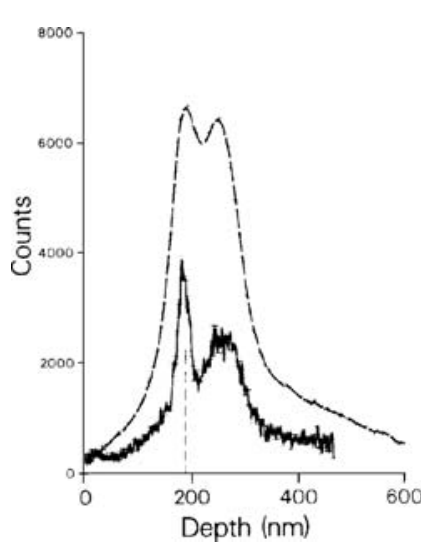

Fig. 5. Comparison of depth resolution for the B profile in silica measured at an angle normal (upper curve) to the sample and at an angle much larger than normal (lower curve) ${ }^{31)}$ (Reprinted with permission from ref. 31. Copyright 1985, American Vacuum Society)

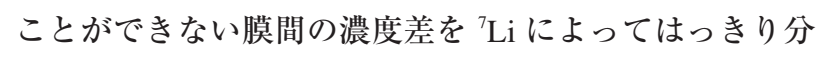
離することができる。

粒子の測定角度 $(\theta)$ は，これを大きくすることによ って粒子の透過距離が大きくなり, 単位深さ当りのエネ ルギー損失量が $1 / \cos \theta$ 倍で大きくなるため分解能が良

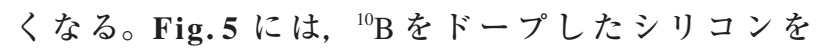
$1000^{\circ} \mathrm{C}$ でアニーリングした試料を, $\theta=0^{\circ}$ と $\theta=75^{\circ}$ で測 定した ${ }^{10} \mathrm{~B}$ の分布曲線を示す ${ }^{31}$ 。角度を大きくとること により，アニーリングで生成した表面の酸化被膜層中 の ${ }^{10} \mathrm{~B}$ 分布がさらに明確になった。このような測定は, ダイヤモンド状多層膜にも適用された ${ }^{32,33)}$ 。以上のよう に, 物質中の阻止能の大きな粒子を大きな $\theta$ で測定す ることにより，深さ分解能が良くなる。

同時計数法：(n, $\alpha)$ および $(\mathrm{n}, \mathrm{p})$ 反応では, 2 種類の 粒子が同時に反対方向に放出される。それらの粒子の同 時計数および飛行時間測定によって深さ分解能を向上さ せる試みもある。同時計数法では, 深さ分解能の改善は 大きくなく, 試料を二つの粒子が透過できる厚さにしな ければならないという制約もあるが，バックグラウンド 計数が低下し, 計数率が増加するため感度が大幅に改善 される ${ }^{34)}$ 。

飛行時間測定法：飛行時間（TOF）法は, 粒子の飛行 時間からより, 精密なエネルギースペクトルを測定しよ うとするものである。この方法では, 荷電粒子が試料表 面から現れる際多量に放出される電子を検出し, これを スタート信号として粒子の飛行時間を測定しょうとする

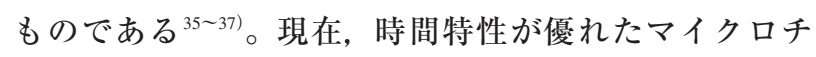
ヤンネルプレート（MCP）を粒子と電子の検出に用い て実験が行われているが, 電子線の検出効率が低く, 満
足のいく粒子スペクトルが得られていない。さらに電子 の捕集効率を改善するため, 磁場と電場の改良が検討さ れている。

\section{4. 応用}

$\mathrm{NDP}$ は, $\mathrm{p}$ 型シリコン半導体のドーパントとして重要 な B に最も高感度であることから, 開発当初から B の インプラント研究や半導体材料開発に応用された。近年 は, さらにマイクロ電子素子やエレクトロクロミック素 子, そして Li イオン電池などの最先端電子素子等に応 用が拡大されている。本稿では, 1990 年代以降に報告 された応用研究を紹介する。

ダイヤモンド，ダイヤモンド状炭素（DLC）および 立方晶窒化ホウ素 (c-BN)：Bをドープしたダイヤモン ドは半導体となり, 高温でも使用可能な高電流の電界効 果トランジス夕 (FET) への利用が期待されている。 $\mathrm{NDP}$ は, $\mathrm{B}_{2} \mathrm{H}_{6}$ を原料ガスに混合する化学蒸着法 （CVD）によってBをドープした人工ダイヤモンド膜の 合成研究に使われた ${ }^{38,39)}$ 。 $1100^{\circ}$ でアニーリングして も ${ }^{10} \mathrm{~B}$ 濃度分布に変化が少ないことから, $\mathrm{B}$ は夕゙イヤモ ンド結晶の格子間よりもむしろ格子に配置されていると 推定された ${ }^{14)}$ 。

一方 DLC は, 電子素子材料としての将来性, そして その硬さと優れた潤滑性から各種材料のコーティング材 としても注目されている。このことから, NDP は質量 分離したイオンビーム蒸着法によって調製し, B および $\mathrm{N}$ をドーピングした DLC 膜の分析に適用された ${ }^{40)}$ 。さ らに，B をドープした DLC 膜とドープしない DLC 膜を 交互に重ねた多層膜試料による, ${ }^{10} \mathrm{~B}$ 分布曲線の分離法 の研究も行われた ${ }^{32,33) 。 ~}$

c-BN も DLC と同様にその硬さと潤滑性から半導体素 子や, 耐摩耗性, 低摩擦コーティング材として注目され ている。c-BN 膜中の B/N 比が膜の安定性に影響するこ とから, シリコン基板上に物理的気相成長（PVD）法で 調製された薄膜の $\mathrm{B} / \mathrm{N}$ 比の測定が行われた ${ }^{41,42)}$ 。c-BN 膜の粒子エネルギースペクトルを Fig. 6 に示す。 ${ }^{10} \mathrm{~B}$ の 分析には $1472 \mathrm{keV}^{4} \mathrm{He}$ が, そして $\mathrm{N}$ の分析には ${ }^{14} \mathrm{~N}$ $(\mathrm{n}, \mathrm{p}){ }^{14} \mathrm{C}$ 反応で生成する $584 \mathrm{keV}{ }^{1} \mathrm{H}$ が使われる。しか し, ${ }^{1} \mathrm{H}$ ピークには ${ }^{10} \mathrm{~B}$ の $840 \mathrm{keV}{ }^{7} \mathrm{Li}$ ピークの影響が大 きい。このため, ${ }^{4} \mathrm{He}$ と ${ }^{1} \mathrm{H}$ を吸収しないで ${ }^{7} \mathrm{Li}$ 粒子の みを吸収する, $1.5 \mu \mathrm{m}$ 厚ポリエステル膜を試料表面に 被せて測定が行われた。眓より, ポリエステル膜を被せ ることによって ${ }^{7} \mathrm{Li}$ 粒子は吸収され, ${ }^{4} \mathrm{He}$ と ${ }^{1} \mathrm{H}$ のピー クだけが観察された。NDPによる B/ $\mathrm{N}$ 比が 1.0 付近の 試料では, 赤外線吸収スペクトルの $1050 \mathrm{~cm}^{-1}$ の波数に 大きな c-BN の吸収が観察され, NDP による精密な組成 


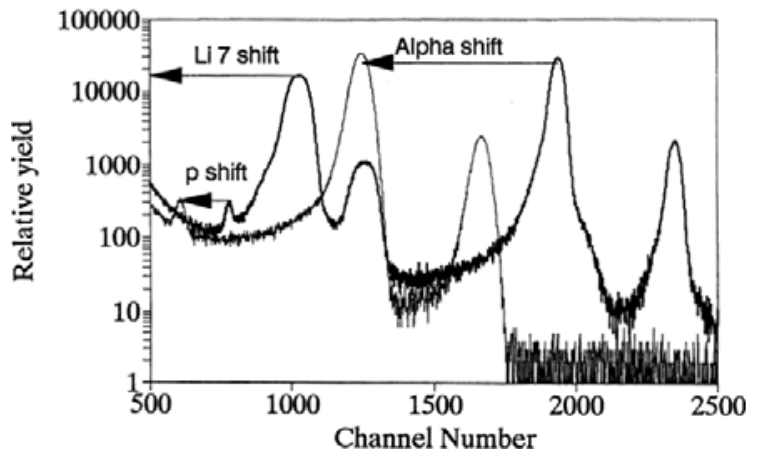

Fig. 6. Comparison of charged particle spectra from a c-BN film with and without the sample covered by a thin polyester film. ${ }^{41)}$

(Reprinted with permission from ref. 41. Copyright 1994, Elsevier Sequoia)

分析と赤外線吸収による構造解析との相関の詳細検討が 可能になった。さらに，シリコン基板上にイオンビーム 支援マグネトロン（IBAM）スパッタリングによって蒸 着した c-BN と類似な特性の非晶質窒化炭素 $\left(\beta-\mathrm{C}_{3} \mathrm{~N}_{4}\right)$ 膜中の $\mathrm{N}$ の分析も報告されている ${ }^{43)}$ 。

エレクトロクロミック素子：電気的に引き起こす可逆 的な酸化還元反応によって色を変えるエレクトロクロミ ック素子は，記憶材料やデイスプレイ材料として応用が 研究されている。素子は $\mathrm{TC} 2, \mathrm{CE}, \mathrm{IC}, \mathrm{WO}_{3}$ そして, $\mathrm{TC} 1$ と呼ばれる層によって構成し, 合計厚さは $1 \mu \mathrm{m}$ と 非常に薄い。素子の色の変化は EC 電極と対電極間の $\mathrm{Li}$ イオンの移動によって起こるとされている。Lamaze ら ${ }^{44)}$ は，エレクトロクロミック素子に電圧を印加し，素 子の作動状態に㧍ける Li イオン挙動を NDP で in-situ 測 定した（Fig. 7)。消色時 Li イオンは主に CE 層に存在 するが，発色時には $\mathrm{IC} と \mathrm{WO}_{3}$ 層に移動することが観 測された。発色時と消色時の Li イオン濃度差から, IC 層を通過する $\mathrm{Li}$ イオン量も求められた。さらに, 種令 の印加電圧下に扔ける光の透過率と, Li イオン濃度分 布変化も調べられた。別のエレクトロクロミック素子も 分析され, $\mathrm{Si}_{3} \mathrm{~N}_{4}$ キャップの $\mathrm{N}$ も測定された ${ }^{45}$ 。 $\mathrm{Li}$ を電 気化学的に拡散させた $\mathrm{WO}_{3}$ 膜中の $\mathrm{Li}$ の測定は，オラン ダのグループも行っている ${ }^{22)}$

Li イオン電池：パソコンや電気自動車の電源として 開発競争が激しい，Li イオン電池の分析にも NDP が使 われている。NDP は，Li イオン電池の正極に使われる, Lithium phosphorous oxynitride（LiPON）とコバルト酸 Li $\left(\mathrm{LiCoO}_{2}\right)$ 膜（厚さ約 $1 \mu \mathrm{m} ）$ の調製法の研究に利用され た ${ }^{46)}$ 。イオンビーム支援蒸着法（IBAD）法によってガ ラス基板上に合成された LiPON 膜中の $\mathrm{Li} と \mathrm{~N}$ は NDP で分析し, $\mathrm{LiCoO}_{2}$ 膜は NDP と機器中性子放射化分析

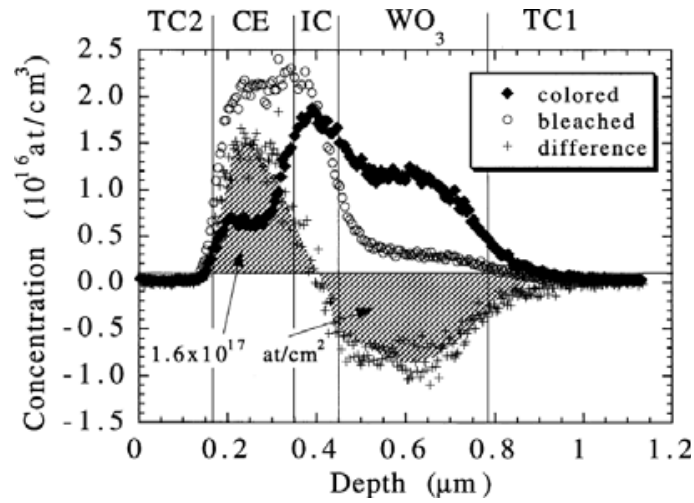

Fig. 7. Depth profile of $\mathrm{Li}$ in an electrochromic device measured under fully colored and fully bleached states. ${ }^{44)}$ (Reprinted with permission from ref. 44. Copyright 1999, John Wiley \& Sons, Ltd.)

（INAA）で Li とCo が分析された。本分析により， IBAD 法による正極用 $\mathrm{LiPON}$ と $\mathrm{LiCoO}_{2}$ 膜の製造条件が 明らかにされた。さらに, 既成の電池を使用し, Li イ オン電池の経年劣化メカニズムを調べる研究も行われ た ${ }^{47,48)}$ 。実際の使用条件に近い充電と放電を繰り返した 正極と負極中の $\mathrm{Li}$ の NDP 測定の結果, 経年劣化によっ て黒鉛製負極表面には Li イオンが蓄積され，lithium iron phosphate $\left(\mathrm{LiFePO}_{4}\right)$ の正極中ではインターカレー ション効率の減少が観察された ${ }^{47)}$ 。 Li イオン電池の NDP 測定は, NIST と Texas 大学 Austin 校で行われてい るが，両方の分析結果の比較も行われた ${ }^{49)}$ 。

核融合炉材料開発および高レベル放射性廃棄物処理： 核融合炉では，核反応によって生成する $14 \mathrm{MeV}$ 中性子 がプラズマを閉じ込める反応容器材料との $(\mathrm{n}, \alpha)$ 反応 によって，材料中に多量の ${ }^{4} \mathrm{He}$ が生成する。この ${ }^{4} \mathrm{He}$ によって材料中に気泡が生成し, 表面が剥離するなどし てプラズマ中に不純物が混入する問題が生じる。このよ うな問題を解決するため， ${ }^{3} \mathrm{He}$ をタングステン ${ }^{50,51)}$ 等の 各種核融合候補材料 ${ }^{52}$ 55) にインプランテーションし, 加熱によるアニーリング効果等が調べられている。さら に, 核融合燃料の ${ }^{3} \mathrm{H}$ を原子炉で中性子照射して製造す るため, $\mathrm{Li}$ セラミック中の ${ }^{6} \mathrm{Li}$ の拡散定数の測定も行わ れた ${ }^{19)}$ 。また，放射性廃魯物処理では，核反応によって 長寿命の $\alpha$ 放射体を短寿命核種に核変換する研究で, 関連する各種物質中の ${ }^{3} \mathrm{He}^{56-58)}$ と ${ }^{6} \mathrm{Li}^{59,60)}$ の分析に使われ ている。

その他，光通信材料や高分子膜等への応用もあるが紙 面の制約によって割愛した。 


\section{5. お}

これまで, NDP は電子工業製品開発に有用な分析法 であることを紹介した。電子工業は, 我が国が最も得意 とする基幹産業の一つで, 我が国が今後も世界をリード していくためには新製品の開発は欠かせない。エレクト ロクロミック素子の分析で紹介したように, NDP は単 なる材料の深さ方向分析というだけでなく, 電子素子の 動作状態における元素挙動の in-situ 観察も可能である。 このように, NDP は最先端電子素子開発に必須の分析 法であるので, 我が国での NDP 研究の必要性を痛感す る。幸い, 我が国には NISTにも劣らぬ良質な低エネル ギー中性子ビームが得られる JRR-3M が茨城県東海村の 日本原子力研究開発機構 (原子力機構) にある。筆者ら は, JRR-3M の即発 $\gamma$ 線分析装置に $\mathrm{Al}$ 製箱型真空チェ ンバー $(20 \times 20 \times 30 \mathrm{~cm})$ を設置し, NDPの予備測定を 行った ${ }^{61)}$ 。標準物質（NIST SRM2137）を分析した結果, 半值幅は少し大きいが, ピーク位置は認証值とほぼ一致 した。原子力機構にはパルス中性子ビームが得られる J-PARK もあり, この利用によってパルス特性を利用し たNDPの新たな展開も期待される。原子力機構での NDP 研究は筆者の退職によって中断しているが, 今後 本研究を継続してくれる人が現れることを期待する。

数多くの情報と図の原図を提供していただき, さらに 英文校閲もしていただいた NIST の Downing 博士, そし て文献調查に協力していただいた原子力機構の松江秀明 博士をはじめとする同機構の図書館員に感謝する。

\section{文献}

1) J.F. Ziegler, G.W. Cole and J.E.E. Baglin : J. Appl. Phys. 43, 3809 (1972).

2) G. Mezey, Z. Szökefalvi-Nagy and C.S. Badinka : Thin Solid Films 19, 173 (1973).

3) K. Müller, R. Henkelmann and H. Boroffka : Nucl. Instrum. Methods 129, 557 (1975).

4) J. Kvítek, V. Hnatowicz and P. Kotas : Radiochem. Radioanal. Lett. 24, 205 (1976).

5) A.Z. Nagy, J. Bogancs, J. Gyulai, A. Csoke, V. Nazarov, Z. Seres, A. Szabo and Y. Yazvitsky: J. Radioanal. Chem. 38, 19 (1977).

6) R.G. Downing, R.F. Fleming, J.K. Langland and D.H. Vincent : Nucl. Instrum. Methods Phys. Res. 218, 47 (1983).

7) G.P. Lamaze, R.G. Downing, J.K. Langland and S.T. Hwang: J. Radioanal. Nucl. Chem. 160, 315 (1992).

8) G.P. Lamaze, H. Chen-Mayer, J.K. Langland and R.G. Downing : Surf. Interface Anal. 25, 217 (1997).

9) H. Matsumura, K. Sakai, M. Maeda, S. Furukawa and K. Horiuchi : J. Appl. Phys. 54, 3106 (1983).

10) D. Fink : HMI-B539 (1996).
11) R.G. Downing, J.T. Maki and R.F. Fleming: J. Radioanal. Nucl. Chem. 112, 33 (1987).

12) R.G. Downing, G.P. Lamaze, J.K. Langland and S.T. Hwang: J. Res. Natl. Inst. Stand. Technol. 98, 109 (1993).

13) R.G. Downing and G.P. Lamaze : Neutron News 4, 15 (1993).

14) R.G. Downing and G.P. Lamaze : Semicond. Sci. Technol. 10, 1423 (1995).

15) 山本博之, 江坂文孝, 松江秀明, 笹瀬雅人: ぶんせき 2009, 612 .

16) http://sites.google.com/site/nistndp/

17) S.M. Çetiner, K. Ünlü and R.G. Downing : J. Radioanal. Nucl. Chem. 271, 275 (2007).

18) S.M. Whitney, R.G. Downing, S. Biegalski and D.S. O’ kelly : J. Radioanl. Nucl. Chem. 276, 257 (2008).

19) H.G. McWhinney, W.D. James, E.A. Schweikert, J.R. Williams, G. Hollenberg, J. Welsh and W. Sereatan : J. Nucl. Mater. 203, 43 (1993).

20) W.N. Lennard, H. Geissel, T.K. Alexander, R. Hill, D.P. Jackson, M.A. Lone and D. Phillips : Nucl. Instrum. Methods Phys. Res., Sect. B 10/11, 592 (1985).

21) P. Kotas, J. Obrusnik, J. Kvitek and V. Hnatowicz : J. Radioanal. Chem. 30, 475 (1976).

22) L.H.M. Krings, Y. Tamminga, J. van Berkum, F. Labohm, A. van Veen and W.M. Arnoldbik : J. Vac. Sci. Technol. A 17, 198 (1999).

23) P.A. Dokhale, V.N. Bhoraskar and P.R. Vijayaraghavan : Mater. Sci. Eng. B 57, 1 (1998).

24) J.T. Maki, R.F. Fleming and D.H. Vincent: Nucl. Instrum. Methods Phys. Res., Sect. B 17, 147 (1986).

25) J.F. Ziegler : "Helium, Stopping powers and ranges in all elemental matter”, (Pergamon Press, New York, 1977).

26) J.F. Janni : Atom. Data Nucl. Data Tables 27, 147 (1982).

27) D.I. Thwaites : Radiat. Res. 95, 495 (1983).

28) J.F. Ziegler: "Transport of Ions in Matters (TRIM) Program”, (Yorktown, New York, IBM Corporation Research), (1994).

29) D.S. Simons, R.G. Downing, G.P. Lamaze, R.M. Lindstrom, R.R. Greenberg, R.L. Paul, S.B. Schiller and W.F. Guthrie : J. Vac. Sci. Technol. B 25, 1365 (2007).

30) H.H. Chen-Mayer and G.P. Lamaze : Nucl. Instrum. Methods Phys. Res., Sect. B 135, 407 (1998).

31) W. Vandervorst, F.R. Shepherd and R.G. Downing: J. Vac. Sci. Technol. A 3, 1318 (1985).

32) K.J. Coakley, R.G. Downing, G.P. Lamaze, H.C. Hofsäss, J. Biegel and C. Ronning : Nucl. Instrum. Methods Phys. Res., Sect. A 366, 137 (1995) ; A 515, 892 (2003).

33) M.S. Levenson and K.J. Coakley : Meas. Sci. Technol. 11, 278 (2000).

34) N.R. Parikh, E.C. Frey, H.C. Hofsäss, M.L. Swanson, R.G. Downing, T.Z. Hossain and W.K. Chu : Nucl. Instrum. Methods Phys. Res., Sect. B 45, 70 (1990).

35) S.M. Çetiner and K. Ünlü : Nucl. Instrum. Methods Phys. Res., Sect. A 579, 148 (2007).

36) S.M. Çetiner, K. Ünlü and R.G. Downing : J. Radioanal. 
Nucl. Chem. 276, 623 (2008).

37) E.A. Schweikert and J.F. Welsh, Jr. : J. Radioanal. Nucl. Chem. 215, 23 (1997).

38) G.P. Lamaze, R.G. Downing, L. Pilione, A. Badzian and T. Badzian : Appl. Surf. Sci. 65/66, 587 (1993).

39) S. Gupta, M. Muralikiran, J. Farmer, L.R. Cao and R.G. Downing : J. Mater. Res. 24, 1498 (2009).

40) C. Ronning, U. Greismeier, M. Gross, H.C. Hofsäss, R.G. Downing and G.P. Lamaze : Diamond Relat. Mater. 4, 666 (1995).

41) G.P. Lamaze, R.G. Downing, L.B. Hackenberger, L.J. Pilione and R. Messier : Diamond Relat. Mater. 3, 728 (1994).

42) L.B. Hackenberger, L.J. Pilione, R. Messier and G.P. Lamaze : J. Vac. Sci. Technol. A 12, 1569 (1994).

43) F. Rossi, B. Andre, A. van Veen, P.E. Mijnarends, H. Schut, F. Labohm, M.P. Delplancke, H. Dunlop and E. Anger : Thin Solid Films 253, 85 (1994).

44) G.P. Lamaze, H.H. Chen-Mayer, M. Badding and L. Laby : Surf. Interface Anal. 27, 644 (1999).

45) G.P. Lamaze, H.H. Chen-Mayer, A. Gerouki and R.B. Goldner : Surf. Interface Anal. 29, 638 (2000).

46) G.P. Lamaze, H.H. Chen-Mayer, D.A. Becker, F. Vereda, R.B. Goldner, T. Haas and P. Zerigian : J. Power Sources 119-121, 680 (2003).

47) S.C. Nagpure, R.G. Downing, B. Bhushan, S.S. Babu and L. Cao : Electrochim. Acta 56, 4735 (2011).

48) S. Whitney, S.R. Biegalski, Y.H. Huang and J.B. Goodenough : J. Electrochem. Soc. 156, A 886 (2009).

49) S.M. Whitney, S.R.F. Biegalski and R.G. Downing : J.
Radioanal. Nucl. Chem. 282, 173 (2009).

50) S.B. Gilliam, S.M. Gidcumb, D. Forsythe, N.R. Parikh, J.D. Hunn, L.L. Snead and G.P. Lamaze : Nucl. Instrum. Methods Phys. Res., Sect. B 241, 491 (2005).

51) S.B. Gilliam, S.M. Gidcumb, N.R. Parikh, D.G. Forsythe, B.K. Patnaik, J.D. Hunn, L.L. Snead and G.P. Lamaze : J. Nucl. Mater. 347, 289 (2005).

52) K. Unlü and D.H. Vincent : Nucl. Instrum. Methods Phys. Res., Sect. A 299, 606 (1990).

53) H. Eleveld, A. van Veen, F. Labohm and M.W. de Moor : J. Nucl. Mater. 212-215, 971 (1994).

54) K. Ünlü and D.H. Vincent : Nucl. Sci. Eng. 110, 386 (1992).

55) K. Ünlü, M. Saglam and B.W. Wehring : Nucl. Instrum. Methods Phys. Res., Sect. A 422, 885 (1999).

56) E.A.C. Neeft, R.P.C. Schram, A. van Veen, F. Labohm and A.V. Fedorov : Nucl. Instrum. Methods Phys. Res., Sect. B 166/167, 238 (2000).

57) P.M.G. Damen, Hj. Matzke, C. Ronchi, J.-P. Hiernaut, T. Wiss, R. Fromknecht, A. van Veen and F. Labohm : Nucl. Instrum. Methods Phys. Res., Sect. B 191, 571 (2002).

58) P.M.G. Damen, A. van Veen, F. Labohm, H. Schut and M.A. van Huis : J. Nucl. Mater. 319, 65 (2003).

59) J. Vacík, V. Hnatowicz, J. Červená, V. Peřina, R. Mach and I. Peka : Nucl. Instrum. Methods Phys. Res., Sect. B 139, 264 (1998).

60) J. Vacik, H. Naramoto, J. Cervena, V. Hnatowicz, I. Peka and D. Fink : J. Nucl. Mater. 289, 308 (2001).

61) 米沢仲四郎, 松江秀明: 第 61 回分析化学討論会講演 要旨集, 1E08 (2000). 